\title{
Pathological Studies on Lasiodiplodia theobromae the Causal Agent of Gummosis Infected Khaya grandifiolia
}

\author{
Chukunda, F.A.; Alapiki, F.U.
}

Department of Forestry and Environment, Faculty of Agriculture, Rivers State University, Port Harcourt, Nigeria

Article No.: 071018095

Type: Research

DOI: 10.15580/GJBS.2019.1.071018095

Submitted: 10/07/2018

Accepted: $17 / 07 / 2018$

Published: 02/04/2019

${ }^{*}$ Corresponding Author

Chukunda, F. A.

E-mail: onyifrank2002@yahoo.com

Phone: 08037501179

Keywords: Pathological Studies,

Lasiodioplodia theobramae,

Gummosis, African mahogany.
The objective of this research was carried out the pathological studies on Lasiodioplodia theobramae the causal agent of gummosis infected African mahogany. The experiment was laid out in a completely randonized design (CRD) with five replicates. The effects of temperature and light and darkness on mycelial growth of $L$. theobromae were evaluated. The fungus grew from $20-40^{\circ} \mathrm{C}$ with optimum growth observed at $25-35^{\circ} \mathrm{C}$ on potato dextrose agars. On the $10^{\text {th }}$ day, mycelial growth at $25-35^{\circ} \mathrm{C}$ was $(15.6 \mathrm{~mm} \pm 0.0-30.6 \mathrm{~mm} \pm$ $0.05 ; 18.4 \mathrm{~mm} \pm 0.28-32.5 \mathrm{~mm} \pm 0.10$ ). There was significant effects of light and darkness on the mycelial difference $(P>0.05)$ on the growth of $L$. theobromae. It is recommended from this research work that environmental factor such as temperatures; light/darkness significantly supported the growth of Lasiodioplodia theobramae. 


\section{INTRODUCTION}

African Mahogany (Khaya grandifiolia): Local Names English (Nigerian mahogany, ivory Coast mahogany, Gold Coast mahogany, African mahogany); French (acajoud' Affique, acajou); German (rotes-Khaya, mahagoni); Indonesian (kaya); Trade name African mahogany. (Opuni-Frimpong, 2006, Lemmens, 2008).

Khaya grandifiolia is distributed from Côte d'Ivoire east to Cameroon and south to Cabinda (Angola); it possibly also occurs in Guinea, Liberia, the Central African Republic and Congo. It is fairly widely grown in plantations within its natural area of distribution but also in tropical Asia and tropical America.(Abdelgaleil et al., 2005) Evergreen or deciduous or monoecious large to very large tree up to $60 \mathrm{~m}$ tall, bole branchless for up to $30 \mathrm{~m}$, usually straight and cylindrical, up to $160-210 \mathrm{~cm}$ in diameter, with large buttresses up to $2-4 \mathrm{~m}$ high. Sometimes extending into prominent surface roots; bark surface brown and slightly rough, exfoliating in small circular scales leaving a pock-marked, mottled greyish brown and orange brown surface, inner bark pink to reddish; crown massive and rounded twigs glabrous. (Andre, 2011; Lemmens, 2008).

Leaves arranged spirally but clustered near ends of branches, paripinnately compound with 3-7 pairs of leaflets; stipules absent; petiole $1-4 \mathrm{~cm}$ long, rachis 6$20 \mathrm{~cm}$ long: petiolules $0.5-1 \mathrm{~cm}$ long; leaflets opposite, oblong to oblong-elliptical, $5-14 \mathrm{~cm} \times 2-6 \mathrm{~cm}$, cuneate to obtuse and slightly asymmetrical at base, distinctly acuminate at apex, margins entire, leathery, glabrous, pinnately veined with 5-10 pairs of lateral veins inflorescence an axillary panicle up to $20 \mathrm{~cm}$ long.

However, since 1999 a high incidence of leaf spot caused by the fungus; Thanatephorus cucumers (teleomorph of Rhizoctonia solani) has been observed, causing numerous lesions on leaves of larger trees and $100 \%$ leaf fall in seedlings. Seeds are commonly attacked by seed-boring beetles and eaten by small rodents. Attacks of living trees by wood borers (Apate spp.) have been observed. The bark of saplings is sometimes eaten by porcupines and squirrels, which can kill the plants. In nurseries in Cote d'Ivoire seedlings are frequently attacked by psyllids (Phacosema spp.), bugs and scale insects, after which they are infested by secondary fungal pathogens, resulting in a smut blackening the leaves. (Abdelgaleil et al., 2005 and Nwoboshi, 1982).

Fungal gummosis was initially observed in the United States near Fort Valley, Georgia, during the 1960s. It subsequently spread to other production areas of the Southeast. The disease was independently discovered at about the same time in Japan, where it is described as peach blister canker or ibokawa byo, and was later reported in China and Australia. This disease, characterized by symptoms associated with bark lenticels, contributes to a general decline of trees. (Weaver, 1974; 1979; Beckman et al., 2003). Symptoms of fungal gummosis are caused by a physiological race of Botryosphaeria dothidea (Moug. Fr.). Other Botryosphaeria species have been reported to cause peach gummosis in the United States (Pusey and Bertrand, 1993). However, these species are primarily wound invaders that are not known to cause infections at lenticels. B. rhodina (Cooke) Arx is relatively rare on peach. B. obtusa (Schwein.). Shoemaker is very common in the Southeastern United States, but its importance as a peach pathogen is unclear. B. obtusa is localized in dead tissue and outer bark (rhytidome) and is absent or in the newly infected cortex and phloem (Pusey et al., 1995; Weaver, 1974).

The earliest fungal gummosis symptoms appear on young bark of vigorous trees as blisters 1 to $6 \mathrm{~mm}$ in diameter, generally each with a lenticel at its center. These raised areas are due to an abnormal multiplication of plant cells (Hyperplasia) in response to the causal organism at the lenticel. Removal of outer bark with a knife reveals diseased tissue at the lenticel margin surrounded by the hyperplastic tissue. Blisters may be observed late in the season when infection occurs or the following spring. By the end of the second season, the area of necrosis surrounding lenticels has enlarged, and the hyperplasia is often less visible or absent. Some second season necrotic lesions exude resins. Lesions that appear in the second season after infection may or may not be preceded by the formation of blisters (Pusey 1993; Pusey and Bertrand, 1993).

Beginning when trees are 2 or 3 years old, sunken necrotic lesions encircling lenticels can be seen on the trunk and major branches. Typically, copious resin exudate is associated with lesions at multiple sites. Lesions of $2 \mathrm{~cm}$ or more in diameter on the oldest bark may coalesce to form large cankers (Figure 2.1). Phloem and cortex are primarily affected however, necrosis may extend to the xylem. Peach branch with blisters caused by the fungus Botryosphaeria dothidea (Pusey et al., 1986)

The fungus overwinters in diseased bark and in dead and dying wood, where it produces an abundance of spores. It spreads within the orchard mainly by dispersal of conidia in rainwater. In the Southeastern United States, asexual spores of the fungus are present from March through October. Infections at lenticels develop from March through August, but May through July is the key infection period. The fungus also invades through wounds, causing cankers. Cankers may remain active for more than one year and lead to secondary infections at lenticels. Blossoms, leaves, and fruits are not infected (Weaver, 1974).

Regrettable there are limited information about the diversity of Lasiodiplodia theobromae. Lack of information on host range of $L$. theobromae on the trees found in Aboretum of Forestry and Environment, Rivers State University, Nkpolu-Oroworukwo, Port Harcourt. Therefore, the present study was undertaken to observe the influence of environmental factors on the mycelial growth of Lasiodiplodia theobromae. 
This research is aimed at investigating the pathological studies on Lasiodiplodia theobromae the causal agent of gummosis infected African mahogany.

Specific objectives of this research were to:

isolate and identify fungal pathogens associated with infected leaves and stem bark of African mahogany.

(ii) determine effect of temperature on the mycelial growth of Lasiodipodia theobromae.

(iii) assess the effect of light and darkness on mycelial growth of Lasiodiplodia theobromae.

\section{MATERIALS AND METHODS}

\section{Study Area}

The study was carried out at the laboratory of Forestry and Environment (Pathology Unit) and Food Science and Technology, Rivers State University, Nkpolu Oroworukwo, Port Harcourt.

\section{Sample Collection}

The infected diseased plant parts showing typical symptoms of gummosis disease were collected from stem bark and leaves portions of diseased African mahogany tree from Aboretum of Forestry and Environment, Rivers State University, Port Harcourt.

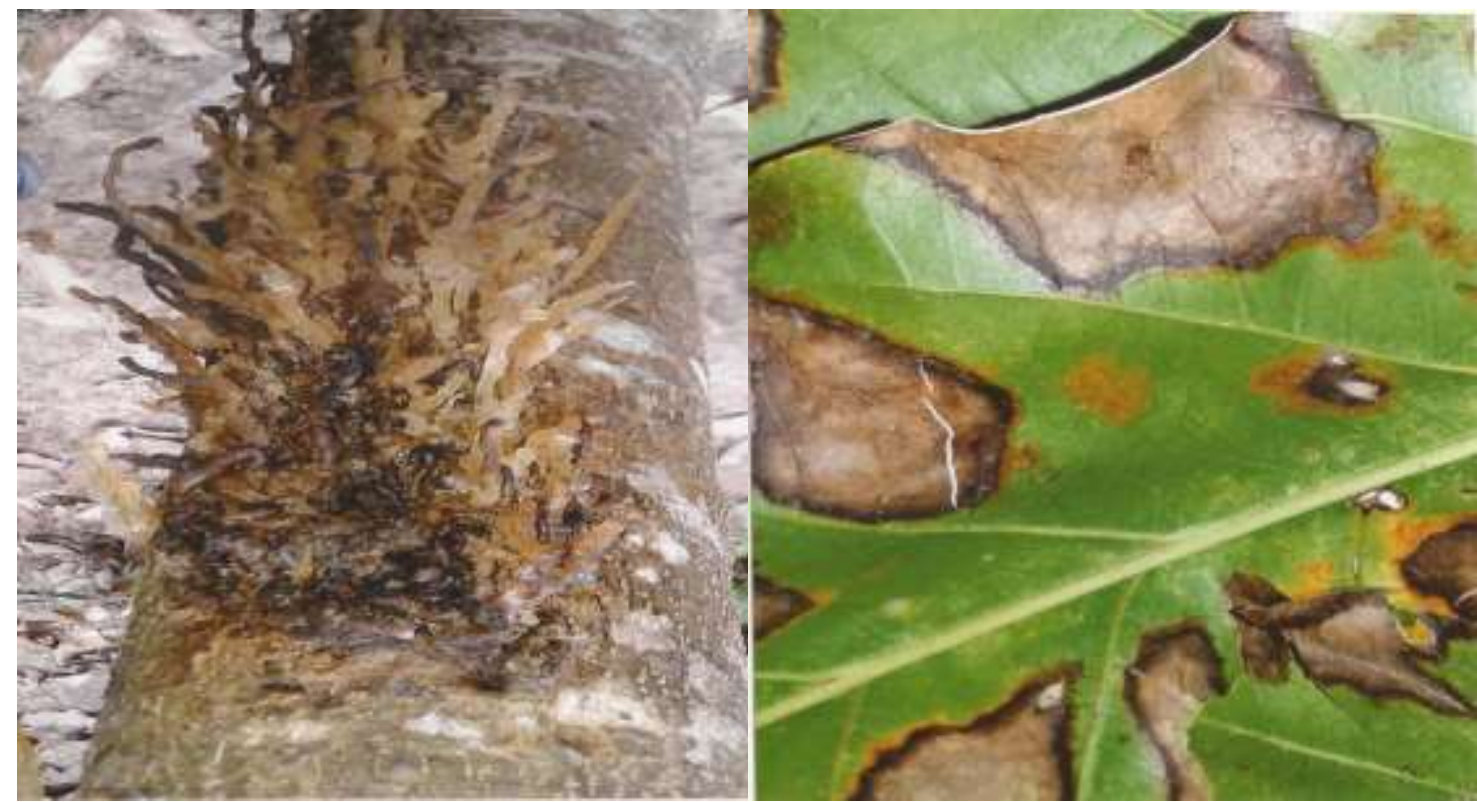

Figure 1: Infected Stem and leaf of African mahogany

\section{Isolation and Identification of Pathogen}

The associated pathogens of African mahogany were isolated from the infected stem barks and leaves as seen in Plate 1 (Pathak, 1987). The infected bark tissues (lesions) and leaves were cut into small pieces $3-4 \mathrm{~mm}$ in size with help of sterilized knife. The pieces were surface sterilized in $2 \%$ Sodium hypochlorite solution for 3 minutes followed by five washing with sterile distilled water. The surface sterilized pieces of stem barks and leaves were then placed on three layers of moistened fitter paper in Petri dishes (Saleem and Nasir, 1991). All Petri dishes were incubated at $28 \pm 2^{0} \mathrm{C}$, for $3-5$ days (Punithalingam, 1976). The fungi were examined under microscope and maintained on pure culture plates at room temperature (Ukomia and Chukunda 2016; Chukunda and Offor, 2015; Pathak, 1987). The frequency of occurrence of fungi was calculated using the formula:

$\%$ Frequency occurrence $=\frac{\text { Number of fruits/seeds containing fungi }}{\text { Total number of fruits/seeds plated }} \times \frac{100}{1} \quad$ (Chukunda, 2014, Ukoima et al., 2013).

\section{Effect of Temperature Lasiodiplodia theobromae \\ on the Growth of}

Five millimeter culture disc of $L$. theobromae were cut with sterilized Cork borer from advancing margin colonies of the fungus and inoculated on PDA plates. The effect of temperature on mycelial growth of $L$. 
theobromae was evaluated on potato dextrose agar (PDA). The inoculated plates were placed in an inoculating chamber and incubated at $15,20,25,30$, $35^{\circ} \mathrm{C}$ in the dark. Each treatment was replicated three times. At each temperature the plates were arranged in a completely randomized design (CRD). Colony diameters were measured along two axes perpendicular to one another. The measurement of the mycelial growth was calculated after 5, 10 and 15 days of inoculation (Ukoima and Chukunda, 2016).

\section{Effect of light and darkness on mycelial growth of $L$. theobromae}

The effect of light and darkness on mycelial growth of isolated fungus $5 \mathrm{~mm}$ culture discs were cut with the sterilized cork borer from advancing margin of the colonies of $L$. theobromae and inoculated on PDA plates at 5 days interval for 15 days. Carbon paper was used to wrap the Petri dishes for darkness, while unwrapped Petri dishes were used for light exposure. All the Petri dishes were incubated at $28 \pm 2{ }^{\circ} \mathrm{C}$ in three replicates under continuous light and darkness, (Kausar et al., 2009).

\section{Experimental Design and Statistical Analysis}

The experiment was laid out in a Completely Randomized Design (CRD). The treatments were replicated three time. Data collected were analyzed by analysis of variance (ANOVA) using SPSS Genstat software as described by Steel and Torrie (1980).

\section{RESULTS}

\section{Fungi Isolated from Infected Parts of African mahogany}

The results on the frequency of occurrence of fungal isolates of infected parts of leaves and stem bark tissues were of obtained from the Aboretum of Department of Forestry and Environment, Rivers state University, Nkpolu-Oroworokwo, Port Harcourt are presented in Table 1 and Plates 1. The result showed that Lasiodiplodia theobromae and Fusarium solani were found in the stem bark and leaves of Khaya grandifiola, L. theobromae $(86.25 \% \pm 2.20 ; 45.26 \% \pm 0.28)$ was the most frequently occurring fungus isolated from both plant parts, while Fusarium solani had $(50.26 \% \pm 0.28$; $45.20 \% \pm 0.22)$.

Table 1: Fungi isolated from infected parts of African mahogany (Mean \pm SD)

\section{Fungal isolate (\%) Infected plant parts (\%)}

\begin{tabular}{lcc} 
& $\begin{array}{c}\text { Stem bark } \\
\text { tissues }\end{array}$ & Leaves \\
\hline $\begin{array}{l}\text { Lasiodiplodia } \\
\text { theobromae }\end{array}$ & $86.25 \pm 2.20$ & $45.26 \pm 0.25$ \\
Fusarium solani & $45.26 \pm 0.28$ & $45.20 \pm 2.22$ \\
\hline
\end{tabular}

Mean \pm SD $(n=5)$
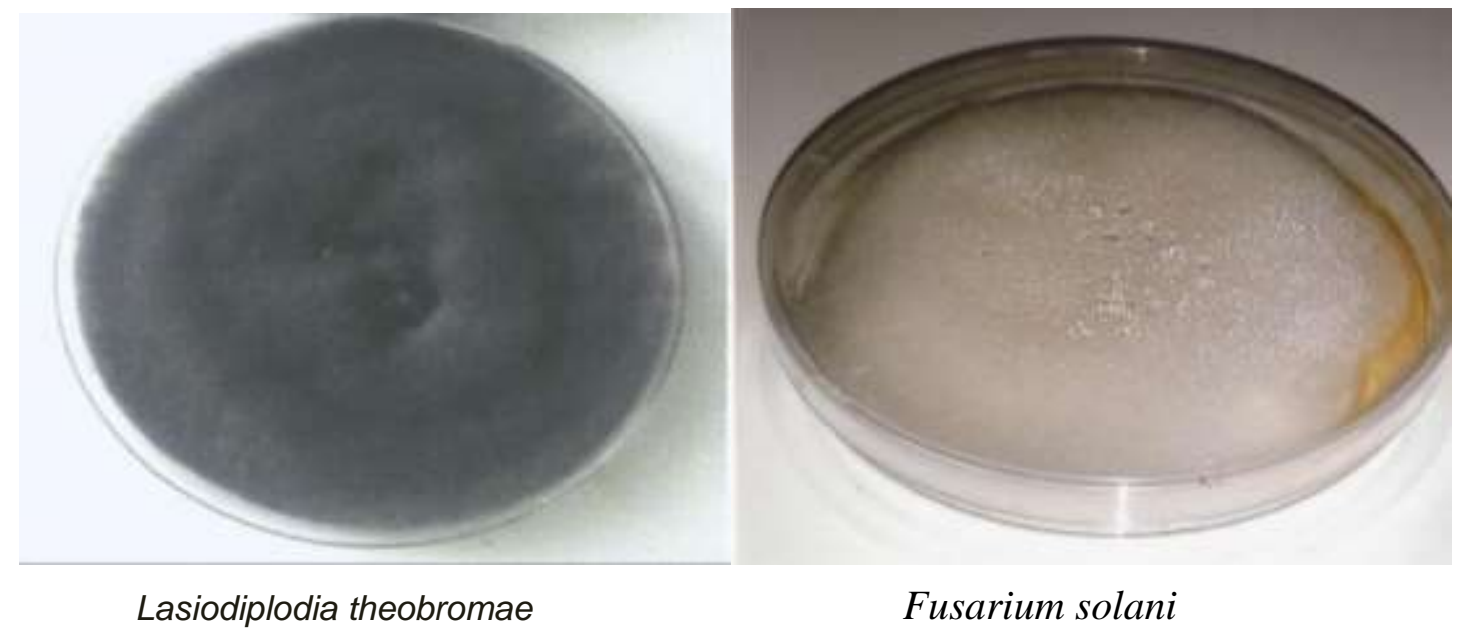

Fusarium solani

\section{Plate 1: Fungi isolated from infected stem bark tissues and leaves of African mahogany}

\section{Effect of different temperature in the mycelial growth of Lasiodiplodia theobromae}

The results on the effect of different temperatures on Lasiodiplodia theobrammae mycelial growth are presented in Table 2. The result showed that different temperature and culture media influenced the mycelial growth of $L$. theobrammae. The relative increase in fungus mycelial growth increased with the increase in temperature. It was observed that the temperature range of $25-35^{\circ} \mathrm{C}$ was optimum for mycelial growth in the PDA 
medium $(15.6 \pm 0.02 \mathrm{~mm}-30.6 \pm 0.05 \mathrm{~mm} ; 18.4 \pm$ $0.28 \mathrm{~mm}-32.5 \pm 0.10 \mathrm{~mm})$.

Table 2: Effect of Different Temperature on the mycelial Growth of Lasiodiplodia theobromae (Mean \pm SD)

Temperature

$\left(\mathrm{t}^{\mathrm{OC}}\right)$

Incubation period/mycelial growth

$(\mathrm{mm}) /$ days

PDA

$5 \quad 10$

$\begin{array}{lll}20 & 12.0 \pm 0.01 & 14.6 \pm 0.81 \\ 25 & 15.6 \pm 0.02 & 18.4 \pm 0.28 \\ 30 & 20.5 \pm 0.03 & 24.0 \pm 0.22 \\ 35 & 30.6 \pm 0.05 & 32.5 \pm 0.10 \\ 40 & 21.5 \pm 0.06 & 23.5 \pm 0.22\end{array}$

Mean \pm SD $(n=5)$ * PDA = Potato dextrose agar

Effect of light and darkness on mycelial growth of Lasiodiplodia theobromae on potato dextrose agar (PDA) incubated at room temperature $\left(28 \pm 2^{\circ} \mathrm{C}\right)$

The result on the effect of light and darkness in Lasiodiplodia theobromae growth on stem bark tissues and leaves portions of Khaya ivorensis are shown in Table 3 . The result indicated that light and darkness significantly $(p \leq 0.05)$ affected the growth of $L$. theobromae at different days. On the $5^{\text {th }}$ day of incubation, $L$. theobromae under continuous darkness mycelial growth on PDA was $(13.5 \pm 0.20 \mathrm{~mm}-18.2 \pm$ $0.30 \mathrm{~mm})$. In continuous light, $L$. theobramae mycelial growth was $(12.3 \pm 0.02 \mathrm{~mm}-16.0 \pm 07 \mathrm{~mm})$. Generally, the highest growth was observed after 10 days for light and darkness on both PDA medium.

Table 3: Effect of light and darkness on mycelial Growth of Lasiodiplodia theobromae on PDA incubated at room temperature $28 \pm 2^{\circ} \mathrm{C}$ (Mean \pm SD)

\begin{tabular}{|c|c|}
\hline \multirow[t]{3}{*}{ Light and darkness } & $\begin{array}{l}\text { Incubation period/mycelial } \\
\text { growth }(\mathrm{mm}) / \text { days }\end{array}$ \\
\hline & PDA \\
\hline & 10 \\
\hline
\end{tabular}

\begin{tabular}{lcc} 
Continuous light & $12.3 \pm 0.02$ & $16.8 \pm 0.22$ \\
$\begin{array}{l}\text { Continuous } \\
\text { darkness }\end{array}$ & $13.5 \pm 0.20$ & $18 \pm 0.30$ \\
\hline \multicolumn{2}{l}{ * PDA = Potato dextrose agar }
\end{tabular}

\section{DISCUSSION}

The results on the frequency of occurrence of fungal pathogens of infected stem bark tissues and leaves of African mahogany (Table 1) indicated that Lasiodiplodia theobromae and Fusarium solani were found to be responsible for the stem and leaves rot of African mahogany collected from the forest arboretum. The stem and leaves pathogens of African mahogany have earlier been implicated by some researchers. Ukoima and Chukunda (2016) reported on the influence physiological factors on mycelia growth of $B$. thobromae, and Rhizopus stolonifer caused serious rotting in Annoan muricata. Similarly, Ukoima et al., (2013) isolated Aspergillus niger from seeds of Jatropha. This is in conformity with present research work.

Chukunda (2014) found Aspergillus niger, Aspergillus flavus, Rhizopus stolonifer, Fusarium pallidoroseum, Botryodiplodia theobromae, Colletotrichum gloeosporoides, Penicillum expansum and Botrytis cinera to be responsible for the serious decay of avocado pears obtained in the Niger Delta ecosystem.

The mycelia growth of lasiodiplodia theobromae (Table 2) showed a variable trend in response to temperature change using potato dextrose agar (PDA). Mycelia growth increased as temperature increased from $20-35^{\circ} \mathrm{C}$ and then decreased with further increase temperature. However, optimum mycelia growth of test fungus occurred at $25-35^{\circ} \mathrm{C}$. This results agreed with those reported by Quroshi and Meah (1991) and Alam et al., (2001) who reported that $25-30^{\circ} \mathrm{C}$ temperatures was optimum for the colony growth and sporulation of lasiodiplodia theobromae.

The results of the effects of light and darkness on fungal growth (Table 3 ) revealed that there was an increase in growth of $L$. theobromae in both light and darkness. Rewal and Grewal (1989) studied the effect of light on conidial germination of three strains of Botrytis cinerea infecting chickpea, and found that conidia of $B$. theobromae germinated best under continuous light and strain $B_{2}, B$. theobromae of germinated well under light and darkness treatment. From the study, it implied that light and darkness are necessary for growth and sporulation of test fungi. This is in agreement with Ahmed (1985) who observed that light promoted the growth and sporulation of Collectotrichum gloeosporoides.

Similarly, Marshi et al., (1959) reported that fungi exhibited varying response to light depending on the light intensity, quality and duration of exposure. Prota (1992), Oladiran and Iwu (1993) and Pihet et al., (2009) reported that ultra violet (UV) radiation or sunlight affected the survival of fungal spores, sclerotia and pycndia. However, some fungi need light to sporulate whereas other fungi sporulate better in darkness. In their investigation, Aspergillus ornatus produced abundant conidia when grown in continuous light and virtually none when grown in dark while Cleistothecia and ascospores are produced in the dark whereas neither is produced in continuous light (Schwemmin, 1960).

Hill (1976) further explained that light inhibits glucose uptake and phosphorylation which caused starvation and retards fungi growth and conidia 
formation. Conversely the growth of Mycospharella pinodes, Aspergillus niger increased when exposed to darkness. (Ukioma and Chukunda, 2016).

On the contrary, Alam et al., (2001) reported that light is not necessary for growth and sporulation of $B$. theobromae, but it enhances the growth and the number of conidia formation which is in partial agreement with the observation of Rewal and Grewal (1989). The increasing glucose in medium, the fungus could utilize it in a certain level and grow properly, and after that level, the fungal physiology does not permit the utilization of glucose for growth of the pathogen. There the fungus might utilize the glucose by different ways instead of growth and formed more pigmentation using more glucose.

According to Cochrane (1958), temperature range permitting reproduction is usually narrower than that permitting growth. Earlier, Leach (1979) had reported variations in optimum temperature requirements within the same species for light induced sporulation at continuous light and continuous darkness Alam et al., (2001) obtained more growth of $L$. theobromae under continuous light and less in continuous darkness. These findings agreed with the present research work where $L$. theobromae test fungi had a good growth performance for both light and darkness.

However, Teyegaga and Clerk (1972) earlier demonstrated the relationship between Cercospora canescens conidia longevity and storage humidity, and observed that in the dark there was longest survival of conidia at low humidity than those under light. Generally the spores stored in the darkness appeared to be more viable than those in light. This may be due to metabolic disruption by light or that light inhibited the spores of test fungi thus reducing their percentage conidial germination.

\section{CONCLUSION AND RECOMMENDATIONS}

\section{Conclusion}

Results from the study revealed that Lasiodiplodia theobromae is a major serious disease affecting the production of Khaya granifiolia from seedling level. Temperature and light/darkness also played an important role in $L$. theobromae growth particularly influenced by the culture medium growth kinetic. Results showed that $L$. theobromae was highest at a temperature of $30-35^{\circ} \mathrm{C}$.

\section{Recommendations}

Based on the present findings the following recommendations are made;

1. To reduce yield losses a good establishment of host range of trees that are not susceptible to this pathogen should be planted.
2. Silvicultural practices will help reduce reoccurrence of Lasiodiplodia theobromae infection on the plantation.

3. Preventing wounds on the test plant is the best way to minimize the spread of $L$. theobromae.

4. Cankered branches of Khaya ivorensis should be pruned to reduce the inoculum from initiating new infection.

5. It is revealed from the study that temperature, light and darkness significantly $(P \leq 0.05)$ affected the mycelial growth of $L$. theobromae.

\section{RFERENCES}

Abdelgaleil, A. A. M Hashinaga, F \& Nakatani, M (2005). Antifungal activity of limonoids from Khaya. ivorensis. Pest Management Science, 61 (2): 186-190.

Alam, S.M., Most-Ferdousi, B., Montaz, A.S., Rafiqul Islam, M. \& Shah-Alam-M (2001). Effect of Temperature, Light and Media on growth, sporulation, formation of pigments and Pycnidia of Botryodiplodia theobromae Pat. Pakistan Journal of Biological Science, 4 (10): 1224-1227.

Andre, R. E (2001). The development of community forests in Cameroon: Origin, current situation and constraints. Networks paper 25b.

Beckman, T. G., Pusey, P. L. \& Bertrand P. F. (2003). Impact of fungal gummosis on peach trees. Horticultural Sciences, 38 (6): 1141-1143.

Chukunda, F. A (2014). Post-harvest fungal diseases of Persea gratissima (C.F. Gaerth) and Dacryodes edulis (G.Don) H.J. Lam, Fruits. Rivers State, University of Science and Technology, Ph.D Rivers State, Nigeria, 21.

Chukunda, F.A \& Offor, U. S (2015). Nutritional composition and fungal spoilage of African pear (Dacryodes edulis) fruits sold in Port Harcourt Metropolis Nigeria. Journal of Research in Biology, 5 (6) $1809-1814$.

Cochrane, V. W (1958). Physiology of fungal. John Wiley \& Sons, Inc. New York, 524.

Lemmens, R.H.M.J (2008). Khaya ivornisis A. Chev. In: Louppe, D. Oteng-Amoako, A.A. \& Brink, M. (Editors). PROTA (Plant Resources of Tropical Africa I Resources vegetales del'Afrique tropicale, Wageningen, Netherlands. Accessed 8 September 2016.

Maheswari, S. K., Singh D. V. \& Sahu A.K. (1999). Effect of several nutrient media, $\mathrm{pH}$ and carbon sources on growth and sporulation of Altemaria altemata. Journal of Mycopathology Research, 37, 21-23.

Oladiran, A. O. \& Iwu, L. N (1993). Studies on fungi associated with tomato fruit rots and effect of environmental factors on storage. Mycologia, 21:157163.

Opuni-Frimpong, E (2006). Improving productivity and conservation of African mahogany: genetic selection, propagation and silvicultural management of 
Hypsipyla robusta (Moore). PhD Forest Science degree thesis, School of Forest resources and Environmental Science, Michigan Technological University, Houghton, United States, 177.

Pathak, V. N (1987). Laboratory manual of plant pathology ( $2^{\text {nd }}$ edition). Oxford and $\mathrm{IBH}$ publishing Co. Pvt. Ltd New Delhi, India.

Punithalingam, E (1976). Botryodiplodia theobromae, $\mathrm{CMI}$ descriptions of pathogenic Fungi and Bacteri No. 519. Kew, Survey, UK, Common Wealth Mycological Institute.

Pusey, P. L. \& Bertrand, P. F. (1993). Seasonal infection of nonwounded peach bark by Botryosphaeria dothidea. Phytopathology, 83: 825829.

Pusey, P. L. (1993). Role of Botryosphaeria species in peach tree gummosis on the basis of differential isolation from outer and inner bark. Plant Disease, 77: $170-174$.

Pusey, P. L., Kitajima, H \& Wu, Y (1995). Peach tree fungal gummosis. In: Compendium of stone fruit diseases. J. M. Ogawa, E. I. Zehr, G. W. Bird, D. F. Ritchie, K. Uriu and J. K. Uyemoto, eds. APS Press, St. Paul, MN. 33-34.

Pusey, P. L., Reilly, C. C. \& Okie, W. R. (1986). Symptomatic response of peach trees to various isolates of Botryosphaeria dothidea. Plant Disease 70: $568-572$.
Rewal, N. \& Grewel, J. S (1989). Effect of temperature, light and relative humidity on conidial germination of three stains of Botrytis cinerea infecting chickpea Indian Phytopathology 42: 79-83.

Saleem A \& Nasir, M. A. (1991). Culture Media Directorate of Agricultural Information, Agriculture Department, Government of the Punjab, Lahore.

Schwemmin, D. J (1960). Light controlled reproductive differentiation in Aspergillus ornatus. University of Michigan, U.S.A.

Steel, R. G. D \& Torrie J. H. (1980). Principles and Procedures of Statistics: A Biometrical Approach. $2^{\text {nd }}$ edition. 597. McGraw Hill Book Company, New York.

Teyegaga, A. \& Clerk, G. C (1972). Germination and survival of conidia of Cercospora caneslens. Tropical Agriculture, 6: 197-204.

Ukoima H. N. and Chukunda, F. A (2016). Influence of physiological factors on mycelial growth of Botryodiplodin theobromae Pat., isolated from Annona muricata. Nigerian Journal of Oil and Gas Technology, 1 (1): 39-50.

Ukoima, H. N., Chukunda, F. A. \& Etim, G (2013). Fungal seed borne disease of Jatropha curcas and their in vitro control measures. International journal of phytofuels and other Allied Sciences, 1:29-35.

Weaver, D. J (1974). A gummosis disease of peach trees caused by Botryosphaeria dothidea. Phytopathology 64: 1429- 1432. 